\title{
Uji Perbandingan Antibiotik Profilaksis Ceftriaxone versus Cefazolin pada Bedah Obstetri dan Ginekologi
}

\author{
Comparative Study of Cefazolin versus Ceftriaxone for Antibiotic Prophylaxis in Obstetrics and \\ Gynecology Surgeries
}

\author{
Asri Rahayu ${ }^{1}$, Fita Rahmawati ${ }^{2}$, Tri Murti Andayani ${ }^{2}$, Ammar Siradjuddin $^{3}$ \\ 1. Magister Farmasi Klinik, Fakultas Farmasi, Universitas Gadjah Mada \\ 2. Departemen Farmakologi \& Farmasi Klinik, Fakultas Farmasi, Universitas Gadjah Mada \\ 3. Kepala SMF Obstetri \& Ginekologi RSUD dr. Dradjat Prawiranegara Serang \\ Submitted: 16-09-2020 Revised: 17-12-2020 \\ Accepted: $24-12-2020$ \\ Korespondensi : Fita Rahmawati : Email : malihahanun@yahoo.com
}

\begin{abstract}
ABSTRAK
Infeksi luka operasi (ILO) adalah komplikasi yang paling umum pada pasien bedah paska operasi yang dikaitkan dengan tingginya morbiditas, kematian dan beban biaya. Komplikasi ini dapat dicegah dengan pemberian antibiotik profilaksis yang tepat. Cefazolin merupakan antibiotik profilaksis yang direkomendasikan, namun di lapangan masih banyak ditemui penggunaan ceftriaxone. Tujuan dari penelitian ini adalah membandingkan luaran klinis dan keamanan cefazolin dan ceftriaxone sebagai antibiotik profilaksis dalam mencegah ILO pada pasien bedah obstetri dan ginekologi. Rancangan penelitian adalah randomized controlled trial double blind. Penelitian dilakukan di RSUD dr. Dradjat Prawiranegara, Serang pada bulan Januari - Juni 2020. Sebanyak 82 subyek yang memenuhi kriteria inklusi dibagi menjadi dua kelompok secara randomisasi blok, 41 subyek diberikan cefazolin dan 41 subyek diberikan ceftriaxon. Luaran klinis diukur melalui efektivitas antibiotik profilaksis dalam mencegah ILO dan luaran keamanan berupa efek samping pada kedua kelompok terapi. Perbandingan efektivitas dan efek samping ditentukan menggunakan uji bivariat (chi-square atau fisher's exact test) serta relative risk (RR). Hasil penelitian menunjukkan efektivitas cefazolin sama dengan ceftriaxone dalam mencegah ILO selama 30 hari ( $\mathrm{RR}=0.89 ; p=0,724 ; 95 \% \mathrm{Cl}: 0,193-3,133)$ dengan jumlah ILO $12,2 \%$ vs $9,8 \%$. Efek samping berupa mual, muntah dan flebitis terjadi pada pemberian antibiotik intravenous push (IVP) pre operasi. Cefazolin mempunyai tingkat keamanan lebih baik dibandingkan ceftriaxone dengan insidensi $9,8 \%$ versus $29,3 \%$ $(\mathrm{RR}=0,33 ; p=0,003 ; 95 \% \mathrm{Cl}: 0.076-0.895)$. Cefazolin sebagai antibiotik profilaksis telah direkomendasikan oleh Kementrian Kesehatan dan Persatuan Obstetri dan GInekologi. Hasil penelitian mendukung rekomendasi penggunaan cefazolin guna mencegah resistensi antibiotik akibat penggunaan ceftriaxone yang berlebihan.
\end{abstract}

Kata kunci: Antibiotik profilaksis; Infeksi Luka Operasi; ceftriaxone; cefazolin

\begin{abstract}
Surgical site infection (SSI) is the most common complication in postoperative surgical patients which is associated with high morbidity, mortality, and cost burden. These complications can be prevented by giving proper prophylactic antibiotics. Cefazolin is a recommended prophylactic antibiotic, but in the practice in Indonesia hospital, there are still many uses of ceftriaxone. This study aimed to compare the clinical outcome and safety of cefazolin and ceftriaxone as prophylactic antibiotics in preventing SSI in obstetric and gynecological surgical patients. The study design was double-blind randomized controlled trial. The data collection was conducted from January to June 2020 at dr. Dradjat Prawiranegara Regional Hospital Serang. A total of 82 subjects who met the inclusion criteria were divided into two groups by block randomization, 41 subjects were given cefazolin and 41 subjects were given ceftriaxone. The clinical outcome was measured by preventing SSI for the effectiveness and side effects for safety outcomes in both groups. The comparison of effectiveness and side effects were analyzed using the bivariate test (chi-square or fisher's exact test) and relative risk (RR). The study showed that the effectiveness of cefazolin was the same as ceftriaxone in preventing SSI for 30 days (RR=0.89; $p=$ $0.724 ; 95 \% \mathrm{Cl}: 0,193-3,133$ ) with the number of SSI $12.2 \%$ vs $9.8 \%$. Side effects included nausea, vomiting, and phlebitis was observed in the administration of antibiotic by intravenous push (IVP) pre-operating. Cefazolin have safetier than ceftriaxone with the incidence of side effects were $9.8 \%$ vs $29.3 \%$ ( $(R R=0,33$; $p=0.003 ; 95 \% \mathrm{Cl}: 0.076-0.895)$. Cefazolin is an antibiotic recommended by Indonesian Ministry of Health
\end{abstract}


and the Association of Obstetrics and Gynecology. This study encourages the use of cefazolin to prevent resistance due to ceftriaxone to overuse.

Keywords: prophylactic antibiotics; surgical site infection; ceftriaxone; cefazolin

\section{PENDAHULUAN}

Bedah obstetri dan ginekologi merupakan prosedur pembedahan yang sering dilakukan di Indonesia. Prosedur bedah memiliki resiko terjadinya infeksi luka operasi (ILO) yang dikategorikan sebagai hospital-acquired infections (HAIs) ${ }^{1}$. prevalensi kejadian ILO pada bedah obstetri dan ginekologi di indonesia bervariasi yaitu antara $3-19,4 \% \%^{2,3}$. Terdapat beberapa faktor risiko yang secara signifikan mempengaruhi kejadian ILO diantaranya body mass index( $p=0,016)$, blood loss intraoperative $(p=0,032)$ dan lama rawat post operasi $(p=0,02)^{2,3,4}$.

Berdasarkan Guideline for the Prevention of Surgical Site Infection 20171, kejadian ILO dapat dicegah hingga $50 \%$ dengan cara pemilihan antibiotik profilaksis yang tepat dan sesuai dengan strategi evidence based 1 . Pemilihan antibiotik profilaksis yang tepat dapat menurunkan angka kejadian ILO dengan mengurangi keberadaan bakteri pada daerah luka saat operasi. Akan tetapi selain memberi manfaat, antibiotik profilaksis dapat meningkatkan resiko terjadinya infeksi jamur dan resistensi antibiotik, jika cara penggunaanya tidak tepat ${ }^{5}$.

Dokter bedah cenderung menyukai penggunaan antibiotik profilaksis dengan cakupan spektrum yang lebih luas, seperti cefoperazone, ceftriaxone dan cefotaxime dibandingkan dengan cefalosporin generasi pertama dan kedua ${ }^{5}$. Penggunaan ceftriaxone sebagai antibiotik profilaksis pada beberapa prosedur pembedahan tidak sesuai dengan hasil kultur dan sensitivitas eksudat luka ${ }^{6}$. Penggunaan antibiotik yang tidak sesuai salah satunya adalah memicu resistensi bakteri terhadap antibiotik ${ }^{6}$. Penelitian Baron $\mathrm{dkk}^{7}$ menyatakan penggunaan ceftriaxone secara berlebihan signifikan berhubungan erat dengan terjadinya peningkatan ESBL $(p<0,005)^{7}$.
Berdasarkan pola kuman di RSUD dr. Dradjat Prawiranegara Serang Banten periode Desember 2017 - Juni 2018 di Bangsal Obstetri dan Ginekologi Wijaya Kusuma ${ }^{8}$, jenis kuman didominasi oleh bakteri gram positif seperti Staphylococcus aureus, Diplococcus Gram positif, dan Staphylococcus albus dan terjadi peningkatan angka kuman Extended-spectrum beta-lactamase (ESBL) sebesar 13,2 \% dibandingkan periode sebelumnya ${ }^{8}$.

Cefazolin menjadi pilihan antibiotik profilaksis bedah di banyak prosedur karena profilnya yang menguntungkan, biaya yang rendah dan aktivitas target terhadap mikroorganisme yang biasa ditemui selama prosedur pembedahan'. Studi-studi penelitian terbaru yang membandingkan cefazolin dengan antibiotik lain pada bedah obsgin secara simultan jumlahnya sangat terbatas ${ }^{10}$. Studi penelitian yang membandingkan cefazolin dengan antibiotik lain sebagai profilaksis bedah obsgin dalam mencegah ILO telah dilakukan oleh Phoolcharoen $\mathrm{dkk}^{11}$ dan Jyothi dkk ${ }^{12}$ menyimpulkan cefazolin memiliki aktivitas yang sama dengan ceftriaxone dan amoxicillin clavulanate $(p=0,32 \text { dan } p=0,51)^{11,12}$. Data - data tersebut diperlukan untuk mendukung rekomendasi penggunaan cefazolin guna mencegah resistensi antibiotik akibat penggunaan ceftriaxone yang berlebihan. Oleh karena itu tujuan penelitian ini yaitu untuk membandingkan luaran klinis serta keamanan cefazolin dan ceftriaxone sebagai antibiotik profilaksis pada pasien yang menjalani bedah obstetri dan ginekologi di RSUD dr. Dradjat Prawiranegara Serang.

\section{METODE}

\section{Rancangan Penelitian}

Rancangan penelitian adalah randomized controlled trial (RCT) double blind. Penelitian melibatkan pasien bedah obstetri 
dan ginekologi yang menerima antibiotik profilaksis cefazolin atau ceftriaxone sebelum prosedur pembedahan di RSUD dr. Dradjat Prawiranegara Serang. Periode penelitian Januari - Juni 2020. Penelitian telah mendapatkan persetujuan Komisi Etik Penelitian Kedokteran dan Kesehatan Fakultas Kedokteran Universitas Diponegoro Semarang dengan nomor Ethical Clearance 547/EC/KEPK/FK UNDIP/ XII/2019.

Pengamatan luaran klinis berupa efektivitas cefazolin dan ceftriaxone dalam mencegah kejadian ILO selama 30 hari pengamatan dan pengamatan luaran keamanan berupa kejadian efek samping yang diamati pada subyek penelitian setelah diberikan antibiotik secara intravena sebelum prosedur pembedahan.

\section{Subyek Penelitian}

Populasi pada penelitian ini adalah pasien yang menjalani prosedur pembedahan obstetri dan ginekologi di RSUD dr. Dradjat Prawiranegara Serang. Sebanyak total 82 subyek dilibatkan dalam penelitian ini. Kriteria inklusi adalah pasien dengan semua tindakan bedah obstetri dan ginekologi yang tidak beresiko tinggi, pembedahan bersifat elektif ataupun emergensi, angka leukosit pre operasi $\leq 16.900 / \mathrm{mm}^{3} 13$, bersedia mengikuti penelitian dengan menandatangani informed consent. Pasien yang telah mendapatkan antibiotik $>24$ jam sebelum operasi, alergi terhadap obat yang diteliti, pasien yang masuk ruang ICU paska prosedur pembedahan, mempunyai riwayat penyakit infeksi seperti HV/AIDS atau immunocompromised di eksklusi dari penelitian ini. Subyek dibagi menjadi dua kelompok secara randomisasi, 41 subyek diberikan cefazolin dan 41 subyek diberikan ceftriaxone.

\section{Metode Sampling}

Teknik pengambilan sampel dilakukan secara nonprobability consecutive sampling. Penentuan subyek uji pada dua kelompok penelitian menggunakan teknik acak blok (block randomization) dengan rumus ${ }^{14}$.

$$
\mathrm{n}=\mathrm{n} ! /(\mathrm{m} / 2 ! \mathrm{X} \mathrm{m} / 2 !) \text {. }
$$

Untuk menentukan besar blok, jumlah subyek harus terbagi dua sama besar, dalam penelitian ini sekuene (kode seri) pada kedua kelompok terapi adalah 6, dengan jumlah kombinasi sesuai rumus besar blok adalah $6 ! / 3 ! \times 2 !=20$. Untuk memastikan kelompok perlakuan seimbang pada akhir setiap blok, pada penelitian ini digunakan alat bantu dadu dengan cara menjatuhkan pada tabel sekuene yang telah dibuat.

Jumlah sampel minimal 37 pasien per kelompok yang ditentukan berdasarkan rumus besar sampel uji dua proporsi ${ }^{15}$.

$$
\mathrm{n} 1=\mathrm{n} 2=\left(\frac{\mathrm{z} \alpha \sqrt{2 \mathrm{PQ}}+\mathrm{Z} \beta \sqrt{\mathrm{P} 1 \mathrm{Q} 1+\mathrm{P} 2 \mathrm{Q} 2}}{(\mathrm{P} 1-\mathrm{P} 2)}\right)^{2}
$$

$\mathrm{n} 1=\mathrm{n} 2=$ Besar sampel tiap kelompok; P1 = Proporsi angka kejadian infeksi pada kelompok cefazolin; P2 = Proporsi angka kejadian infeksi pada kelompok ceftriaxone; $\mathrm{P}=$ $1 / 2(\mathrm{P} 1+\mathrm{P} 2) ; \alpha=$ kesalahan tipe $\mathrm{I}=0,05 ; \mathrm{z} \alpha=$ 1.96; $\beta=$ kesalahan tipe $\mathrm{II}=0,01 ; \mathrm{z} \beta=2.32$ $\mathrm{Q}=(1-\mathrm{P})$.

Alokasi subyek penelitian yang diberikan cefazolin dan ceftriaxone (Gambar 1).

Selama periode bulan Januari - Juni 2020 terdapat 94 kasus bedah obsgin. Sejumlah 12 pasien dikeluarkan dalam penelitian dikarenakan beberapa sebab seperti: pasien masuk ICU, pasien demam tinggi dengan suhu $40^{\circ} \mathrm{C}$ post operasi, pasien mendapat antibiotik oral ketika pulang, pasien mendapatkan antibiotik empiris post operasi karena terpasang drain yang berisi cairan post operasi dan pasien tidak datang kembali untuk kontrol di poli rawat jalan sejumlah 6 pasien.

\section{Instrumen Penelitian}

Instrumen yang digunakan dalam penelitian ini adalah case report form (CRF). CRF berisi check list kriteria yang diadopsi dari Center for Disease Control (CDC) ${ }^{1}$, Cinical Guideline for Antimicrobial Prophylaxis in Surgery disusun bersama oleh American Society of Health-System Pharmacy Infectious Disease Society of America16, Surgical Infection Society dan Society for Healthcare epidemiology of America tahun $2013^{16}$. 


\section{Observasi outcome clinic}

Pada penelitian ini luaran klinis yang diamati adalah efektivitas cefazolin dan ceftriaxone yang diberikan single dose secara intravenous (IV) pre operasi dalam mencegah terjadinya ILO. Kriteria diagnosis ILO pada penelitian ini adalah ILO insisional superfisial, yaitu infeksi yang hanya mengenai kulit atau jaringan subkutan pada daerah bekas insisi atau infeksi yang terjadi dalam 30 hari setelah pembedahan ${ }^{1}$. Pengamatan tanda-tanda ILO dimulai dari post operasi selama pasien di ruang perawatan sampai pasien keluar rumah sakit dan kembali untuk melakukan kontrol luka operasi di poliklinik rawat jalan. Monitoring tanda dan gejala ILO dilakukan melalui telepon secara periodik sampai dengan hari ke-30 setelah prosedur pembedahan. Penegakan diagnosis ILO superficial incicional dilakukan oleh dokter obsgin di poli kandungan rawat jalan pada hari ke 7 post rawat inap.

Dalam penelitian ini bentuk ILO yang ditemukan bervariasi mulai dari nyeri dan sakit pada luka pembedahan, luka pembedahan basah, luka kemerahan disertai darah di area pembedahan.Tidak ditemukan adanya pus dari insisi superfisial. Kejadian ILO pada penelitian ini dituangkan dalam catatan perkembangan pasien terintegrasi (CPPT) oleh dokter obsgin.

Terjadinya ILO selain dipengaruhi oleh penggunaan antibiotik profilaksis juga dipengaruhi oleh variabel lain seperti karakteristik pasien meliputi jenis operasi, usia, dan komorbid serta karakteristik pembedahan seperti blood loss intraoperatif, lama rawat inap, anemia, nilai albumin, waktu insisi, dan lama ketuban pecah dini (KPD). Variabel-variabel ini selanjutnya diidentifikasi, untuk mengetahui sebaran pada kedua kelompok subyek uji.

Evaluasi terhadap keamanan penggunaan obat dilakukan melalui monitoring efek samping yang diamati setelah pemberian injeksi cefazolin dan ceftriaxone. Kedua jenis antibiotik ini diberikan 30-60 menit sebelum pembedahan. Efek samping obat diamati setelah pemberian obat hingga waktu operasi. Jenis efek samping obat berupa mual, muntah dan flebitis. Efek samping yang terjadi dilaporkan kepada dokter anestesi untuk dilakukan penanganan lebih lanjut.

\section{Analisis Data}

Data subyek penelitian yang memenuhi kriteria inklusi dianalisis menggunakan statistical package for social science (SPSS) versi 23. Analisis data yang digunakan adalah analisis bivariat. Data karakteristik pasien dan pembedahan dianalisis menggunakan analisis Chi-square atau Fisher's exact test untuk mengetahui ada tidaknya perbedaan karakteristik variabel pada kedua kelompok antibiotik. Untuk mengetahui hubungan antara jenis antibiotik profilaksis sebagai variabel bebas dan insidensi ILO serta efek samping sebagai variabel tergantung digunakan uji Fisher's-exact test. Selanjutnya kekuatan hubungan yang membandingkan antara variabel bebas dan variabel tergantung diketahui dari nilai relative risk (RR) dan $p$ value. Kebermaknaan secara statistik dinilai bermakna jika nilai $p<0,05$.

\section{HASIL DAN PEMBAHASAN}

Karakteristik subyek penelitian disajikan pada Tabel I meliputi prosedur operasi, umur dan komorbid. Pada Tabel II disajikan karakteristik pembedahan yang meliputi blood loss intraoperatif, $\mathrm{Hb}$ pre operatif, nilai albumin, lama rawat, transfusi darah, waktu insisi, durasi ketuban pecah dini (KPD) pada kasus obstetri. Secara keseluruhan karakteristik subyek dan karakteristik pembedahan diantara kedua kelompok terapi tidak didapatkan perbedaan bermakna $(p>0,05)$. Dengan demikian dapat disimpulkan karakteristik yang homogen mendukung validitas penelitian.

Umur pasien pada penelitian ini dibagi menjadi 3 kategori yaitu $\leq 25$ tahun, 26-40 tahun dan $>40$ tahun. Rerata usia pada kelompok cefazolin dan ceftriaxone masingmasing 43 dan 40 tahun dengan rentang usia 17 hingga 76 tahun. Rerata usia pada sebuah studi yang membandingkan efektivitas cefazolin vs amoxicillin clavulanate pada 
Tabel I. Karakterisitk Subyek Penelitian

\begin{tabular}{|c|c|c|c|}
\hline \multirow[b]{2}{*}{ Karakteristik } & \multicolumn{2}{|c|}{ Kelompok Uji } & \multirow[b]{2}{*}{$p$} \\
\hline & $\begin{array}{c}\text { Cefazolin } \\
\mathrm{n}=41\end{array}$ & $\begin{array}{c}\text { Ceftriaxone } \\
n=41\end{array}$ & \\
\hline \multicolumn{4}{|c|}{ Prosedur Operasi } \\
\hline Obstetri & $33(45,8 \%)$ & $39(54,2 \%)$ & \multirow{2}{*}{$0,044^{* 1}$} \\
\hline Ginekologi & $8(80 \%)$ & $2(20 \%)$ & \\
\hline \multicolumn{4}{|l|}{ Umur (tahun) } \\
\hline$\leq 25$ & $11(26,8 \%)$ & $12(29,3 \%)$ & \multirow{3}{*}{$0,523^{* 2}$} \\
\hline $26-40$ & $22(53,7 \%)$ & $24(58,5 \%)$ & \\
\hline$>40$ & $8(19,5 \%)$ & $5(12,2 \%)$ & \\
\hline \multicolumn{4}{|l|}{ Komorbid } \\
\hline Tidak Ada & $33(51,6 \%)$ & $31(48,4 \%)$ & \multirow[t]{2}{*}{$0,790^{* 1}$} \\
\hline Ada & $8(44,4 \%)$ & $10(55,6 \%)$ & \\
\hline
\end{tabular}

Keterangan : *1 Chi-square test ; ${ }^{2}$ Uji Fisher's Exact Test

Tabel II. Karakteristik Pembedahan

\begin{tabular}{|c|c|c|c|}
\hline \multirow{2}{*}{ Karakteristik } & Cefazolin & Ceftriaxone & \multirow[b]{2}{*}{$p$} \\
\hline & $n=41$ & $n=41$ & \\
\hline \multicolumn{4}{|c|}{ Blood loss intraoperatif (ml) } \\
\hline$<500$ & $37(53,6 \%)$ & $32(46,4 \%)$ & \multirow{2}{*}{$0,113^{* 2}$} \\
\hline$\geq 500$ & $4(30,8 \%)$ & $9(69,2 \%)$ & \\
\hline \multicolumn{4}{|c|}{ Lama Rawat ( hari) } \\
\hline$<5$ & $33(50 \%)$ & $33(50 \%)$ & \multirow{2}{*}{$1,0^{* 1}$} \\
\hline$\geq 5$ & $8(50 \%)$ & $8(50 \%)$ & \\
\hline \multicolumn{4}{|l|}{$\mathrm{Hb}$ Pre (g/dl) } \\
\hline$\leq 10$ & $14(50 \%)$ & $14(50 \%)$ & \multirow{2}{*}{$0,592^{* 2}$} \\
\hline$>10$ & $27(50 \%)$ & $27(50 \%)$ & \\
\hline \multicolumn{4}{|l|}{ Nilai Albumin } \\
\hline$<2,5$ & $3(50 \%)$ & $3(50 \%)$ & \multirow[t]{2}{*}{$0,662^{* 2}$} \\
\hline$\geq 2,5$ & $38(50 \%)$ & $38(50 \%)$ & \\
\hline \multicolumn{4}{|c|}{ Transfusi Darah } \\
\hline Tidak Ada & $26(46,4 \%)$ & $30(53,6 \%)$ & \multirow[t]{2}{*}{$0,476^{* 1}$} \\
\hline Ada & $15(57,9 \%)$ & $11(42,3 \%)$ & \\
\hline \multicolumn{4}{|c|}{ Waktu Insisi (menit) } \\
\hline$\geq 30$ & $29(50,9 \%)$ & $28(49,1 \%)$ & \multirow[t]{2}{*}{$1,0^{* 1}$} \\
\hline$<30$ & $12(48,0 \%)$ & $13(52,0 \%)$ & \\
\hline \multicolumn{4}{|c|}{ Lama KPD (jam) } \\
\hline$\leq 8$ & $3(100 \%)$ & $0(0 \%)$ & \multirow[t]{2}{*}{$0,238^{* 2}$} \\
\hline$>8$ & $3(50 \%)$ & $3(50 \%)$ & \\
\hline
\end{tabular}

Keterangan :*1 Chi-square ; ${ }^{* 2}$ Uji Fisher's Exact Test ; KPD ; Ketuban Pecah Dini.

prosedur obsgin 43,2 tahun vs 47,6 tahun ${ }^{12}$. Studi yang dilakukan di Amerika Serikat, menunjukkan terjadi peningkatan kejadian
ILO 1,1\% per tahun dengan usia kisaran 8-65 tahun dan $1,2 \%$ pada usia diatas 65 tahun ${ }^{17}$. Pasien dengan usia $>40$ tahun memiliki factor 
risiko terkena ILO 2,95 kali lebih besar dibandingkan dengan usia 25-40 tahun pada bedah obstetri dan ginekologi ${ }^{4}$ ILO dapat terjadi pada semua kategori usia dan insidensinya meningkat seiring bertambahnya usia. Kelompok pasien usia lanjut dipertimbangkan sebagai faktor risiko terhadap kejadian ILO dikarenakan adanya penyakit penyerta, gangguan aktivitas harian dasar, kerapuhan, adanya gangguan kognitif, penggunaan obat lebih dari satu, status nutrisi, penurunan fungsi imun dan tipe tempat tinggal (nursing home) $)^{17}$. Menurut Anderson $\mathrm{dkk}^{18}$ hubungan antara usia dengan peningkatan risiko ILO kemungkinan lebih disebabkan oleh komorbid atau immunosenescene ${ }^{18}$ Pada penelitian ini rentang umur yang mengalami ILO pada kelompok cefazolin adalah 31 hingga 76 tahun sedangkan pada kelompok ceftriaxone adalah 27 hingga 57 tahun.

Komorbid adalah riwayat penyakit pasien yang diderita sebelum masuk rumah sakit, komorbid yang paling dominan pada penelitian ini yaitu cardiovascular disease (Coronary Artery disease (CAD), Chronic Heart Failure (CHF), Hypertensive Heart Disease (HHD), anemia, asma dan bronchopneumoni. Sebanyak 4 pasien dalam penelitian ini mengalami ILO dengan komorbid diantaranya 2 pasien anemia dengan kadar $\mathrm{Hb}$ pre operasi $<10 \mathrm{~g} / \mathrm{dL}$ dan sisanya masuk rumah sakit dengan riwayat HHD. Penelitian Pathak dkk ${ }^{4}$ dan Chairani $\mathrm{dkk}^{2}$ menyebutkan insidensi ILO terjadi pada pasien dengan komorbid diantaranya obesitas, diabetes, anemia, gizi yang buruk, hipertensi, CAD dan pneumonia ${ }^{4,2}$. Sebanyak $71(69,6 \%)$ pasien dengan komorbid mengalami ILO sebesar 10 $(100 \%)(p=0,003)^{2}$. Sebanyak 239 pasien yang menjalani C-section di RS India, 22 (9\%) diantaranya memiliki komorbid serta secara signifikan berpengaruh terhadap insidensi ILO sebesar 5,76 kali dibanding tanpa komorbid $\quad(p=0,001)^{4} . \quad$ Mamo $\mathrm{dkk}^{19}$ menyebutkan bahwa risiko ILO akan lebih tinggi pada pasien yang memiliki komorbid. Hal ini disebabkan pasien tersebut memerlukan metabolisme ekstra sehingga dapat mengurangi kebutuhan oksigen dan nutrisi pada penyembuhan luka ${ }^{19}$.

Pada penelitian ini rerata blood loss intraoperative dengan volume $\geq 500 \mathrm{~mL}$ pada kelompok cefazolin dibandingkan cetriaxone yaitu $30,8 \%$ vs $69,2 \%$ dan rerata volume darah kedua kelompok adalah $308,05 \mathrm{~mL}$ vs 269,02 $\mathrm{mL}$. Sebuah studi yang dilakukan terhadap 320 pasien dengan prosedur ginekologi di RS Bangkok, rerata blood loss intraoperative pada kelompok cefazolin dibandingkan ceftriaxone (300 mL $\pm 50-1100 \mathrm{~mL}$ vs $300 \mathrm{~mL} \pm 50-2300$ $\mathrm{mL})^{11}$. Blood loss intraoperative merupakan variabel pembedahan yang harus di monitoring selama prosedur pembedahan guna memastikan serum dan konsentrasi antibiotik dijaringan tetap adekuat ${ }^{16}$. Beberapa literatur menyebutkan volume blood loss intraoperative $>1500 \mathrm{~mL}$ berisiko terjadinya ILO $^{16,20}$ oleh karenanya volume darah $>1500$ $\mathrm{mL}$ direkomendasikan pemberian dosis ulangan intraoperative untuk mencegah ILO $^{16,20}$. Semua prosedur pembedahan dengan volume blood loss $>1500 \mathrm{~mL}$ disarankan untuk mengganti volume darah yang hilang dengan transfusi darah ${ }^{18}$. Namun, belum ada dasar ilmiah untuk menahan produk darah yang dibutuhkan oleh pasien dalam rangka menurunkan risiko ILO insisional atau organ/space.

Transfusi darah perioperatif pada kedua kelompok dalam penelitian ini adalah $57,9 \%$ vs $42,3 \%$. Studi Pathak $\mathrm{dkk}^{4}$ dan Chairani $\mathrm{dkk}^{2}$ transfusi darah perioperatif pada prosedur obsgin sebesar $21,48 \%$ dan $38,2 \%{ }^{4,2}$. Menurut pedoman dari SHEA/IDSA dalam Strategies to Prevent Surgical Site Infection in Acute Care Hospitals ${ }^{18}$, transfusi darah dapat meningkatkan risiko terjadinya ILO dengan cara menurunkan fungsi makrofag ${ }^{18}$. Blood loss $>1500 \mathrm{~mL}$ dan setelah menerima transfusi darah kemungkinan menggambarkan adanya kondisi anemia yang parah sehingga kapasitas sel darah merah dalam membawa oksigen yang mengantarkan ke jaringan menurun, adanya potensi kontaminasi, serta transfusi yang berhubungan dengan immunomodulasi 
pada kondisi critical ill. ${ }^{4}$

Waktu insisi pada penelitian ini adalah selisih waktu mulai sayatan pembedahan dengan waktu diberikan antibiotik profilaksis sebelum operasi secara intravena. Waktu insisi <30 menit pada kedua kelompok antibiotik pada penelitian ini adalah $48,0 \%$ vs $52,0 \%$ dan $\geq 30$ menit adalah $28,0 \%$ vs $13,0 \%$, beberapa penelitian pada perosedur bedah obsgin memberikan informasi yang bervariasi yaitu waktu insisi 30-60 menit sebesar 78\%$90 \%$ dan $<30$ menit atau $>60$ menit sebesar $12,0-29,3 \%$ 2,3. Berdasarkan rekomendasi IDSA (Infection Disease Society of America) ${ }^{18}$, pemberian antibiotik profilaksis sebaiknya diberikan pada rentang 30-60 menit sebelum insisi dan diberikan dengan interval yang sesuai dengan waktu paruhnya ${ }^{18}$. Pemberian antibiotik profilaksis yang terlalu dini $(<30$ menit) akan menurunkan konsentrasi efektif antibiotik dalam jaringan dan meningkatkan risiko $\mathrm{ILO}^{16}$.

Pada penelitian ini sejumlah 9 kasus bedah obstetri dengan KPD durasi $\leq 8$ jam dibandingkan $>8$ jam pada kelompok cefazolin vs ceftriaxone yaitu $100 \%$ vs $0 \%$ dan $50 \%$ vs 50 $\%$ serta probabilitas insidensi ILO dengan $\mathrm{KPD}>8$ jam dibandingkan $<8$ jam adalah 0,09 kali $(p=0,03)$. Sebuah studi yang di lakukan terhadap 447 di RS Qatar, kasus prosedur CSection dengan KPD $\leq 8$ jam dibandingkan $>8$ jam dengan proporsi kejadian sebesar 47,7 \% vs $45,9 \%$ dan $9,3 \%$ vs $5,6 \%$ serta probabilitas insidensi ILO $>8$ jam jam sebesar 0,3 kali dibandingkan $\leq 8$ jam $^{21}$. Faktor yang paling sering dikaitkan dengan morbiditas infeksius pada persalinan dengan bedah C-section adalah persalinan yang lama dengan ketuban pecah dini (KPD). Persalinan dengan KPD $>8$ jam adalah persalinan dengan risiko tinggi ${ }^{16,21}$. KPD adalah pecahnya membran korioamniotik utuh yang berfungsi sebagai pelindung melawan infeksi bakteri saat kontraksi selama persalinan. Pecahnya membran membuat permukaan rahim terkontaminasi bakteri ${ }^{16}$. Kejadian KPD pada prosedur obstetri dengan durasi lebih dari 8 jam meningkatkan risiko endometriosis yang akan mengakibatkan terjadinya ILO ${ }^{16}$.
Pada penelitian, sebesar 16 pasien $(19,51 \%)$ menjalani perawatan post operasi> 5 hari dan sisanya menjalani perawatan post operasi < 5 hari. Probabilitas Insidensi ILO pada pasien yang menjalani perawatan $>5$ hari pada penelitian ini sebesar 12,6 kali dibandingkan $<5$ hari. sebuah studi di RS India sebanyak 1173 pasien bedah obsgin dengan durasi rawat inap 7-14 hari yaitu $36,10 \%$ dengan insidensi ILO sebesar 9,6\% (RR: 2,34; $p=0,001 ; 95 \% \mathrm{CI}: 1.43-3,82$ ) dan durasi rawat $>14$ hari yaitu $7,3 \%$ dengan insidensi ILO sebesar 25,5\% （ RR:7,51; $p=0,003$; 95\%CI:4,07-13,84) ${ }^{4}$. Durasi rawat inap yang lama akan meningkatkan risiko kontaminasi bakteri dan menurunkan daya tahan tubuh sehingga pasien lebih mudah terkena $\mathrm{ILO}^{4}$.

\section{Luaran klinis cefazolin dibandingkan ceftriaxone}

Kriteria infeksi yang digunakan pada penelitian ini berupa kejadian ILO. Center for Disease Control (CDC) ${ }^{1}$ menyatakan bahwa infeksi luka operasi ditandai dengan panas, kemerahan, nyeri dan pembengkakan, drainase purulen dari insisi superfisial, tandatanda sistemik demam atau peningkatan jumlah leukosit, serta didapatkan organisme yang terisolasi dari kultur yang diperoleh dari jaringan atau cairan insisi superfisial. Infeksi luka operasi ditegakkan bila didapatkan minimal satu dari gejala tersebut ${ }^{1}$.

Pengamatan terhadap ILO yang ditemukan pada saat kontrol di poli kandungan ditemukan adanya darah di sekitar kulit area pembedahan namun darah tidak ditemukan di area hecting (jahitan). Insidensi ILO pada pasien bedah obstetri dan ginekologi di RSUD dr. Dradjat Prawiranegara Serang periode bulan Januari - Juni 2020 disajikan pada Tabel III. Dalam penelitian ini, tidak terdapat perbedaan secara signifikan antara cefazolin dan ceftriaxone terhadap kejadian ILO $(12,2 \%$ vs 9,8\%) (RR=0,89; $p=0,724$; 95\%CI: 0,193-3,133). Penelitian ini sejalan dengan penelitian sebelumnya dimana cefazolin single dose pre operasi mempunyai efektivitas yang sama dalam mencegah ILO 
Tabel III. Insidensi ILO pada Pasien Bedah Obstetri dan Ginekologi di RSUD dr.Dradjat Prawiranegara Serang periode bulan Januari-Juni 2020

\begin{tabular}{|c|c|c|c|c|}
\hline \multirow{3}{*}{ Kelompok } & \multicolumn{2}{|c|}{ ILO } & \multirow{3}{*}{$P^{*}$} & RR \\
\hline & Tidak ILO & ILO & & \multirow{2}{*}{$95 \% \mathrm{CI}$} \\
\hline & n (\%) & n (\%) & & \\
\hline Cefazolin & $36(87,8 \%)$ & $5(12,2 \%)$ & \multirow{2}{*}{0,724} & \multirow{2}{*}{$0,89(0,193-3,133)$} \\
\hline Ceftriaxone & $37(90,2 \%)$ & $4(9,8 \%)$ & & \\
\hline
\end{tabular}

dibandingkan dengan antibiotik golongan beta laktam seperti ceftriaxone dan amoxicillin clavulanate pada pasien bedah obsgin ${ }^{11,12}$. Pada bedah ginekologi Insidensi ILO pada kelompok cefazolin dibandingkan amoxicillin clavulanate yaitu $0 \quad \%$ vs $5,5 \quad \% \quad(p=1,0)$ sedangkan kelompok cefazolin dibandingkan ceftriaxone yaitu $3,8 \%$ vs $1,9 \%(p=0,32)^{12}, 11$ insidensi ILO pada prosedur bedah C-section kelompok cefazolin vs amoxicillin clavulanate sebesar $2,9 \%$ vs $2 \%(p=0,82)^{12}$.

Ceftriaxone sebagai antibiotik profilaksis pada bedah obsgin tidak tepat karena kurang aktif terhadap Staphylococci dibandingkan dengan cefazolin yang memiliki aktivitas lebih baik terhadap mikroorganisme yang sering diisolasi pada luka operasi dan penggunaan ceftriaxone untuk profilaksis mendorong munculnya organisme resisten 6 . Cefazolin menjadi pilihan antibiotik profilaksis bedah di banyak prosedur karena profilnya yang menguntungkan, biaya yang rendah dan aktivitas target terhadap mikroorganisme yang biasa ditemui selama prosedur pembedahan9. Cefazolin lebih efektif dibanding dengan teiclopanin karena efektif terhadap Staphylococus aureus yang paling sering diisolasi pada luka yang terinfeksi 2 .

Penggunaan cephalosporin generasi pertama (cefazolin) sebagai profilaksis bedah obsgin telah di rekomendasikan oleh Kementrian Kesehatan R..$^{20}$ dan Persatuan Obstetri dan Ginekologi Indonesia (POGI) ${ }^{23}$ berdasarkan kemanjurannya, spektrum aktivitasnya terhadap bakteri penyebab ILO2023. Pilihan antibiotik selain cefazolin apabila pasien mengalami alergi terhadap golongan cephalosporin adalah golongan penicillin spektrum luas seperti amoksisilin-sulbaktam dan apabila dicurigai pada kasus tertentu adanya bakteri anaerob bisa dikombinasikan dengan metronidazol 2023 .

\section{Luaran keamanan cefazolin dibandingkan ceftriaxone}

Parameter luaran keamanan pada penelitian ini adalah kejadian efek samping setelah pemberian antibiotik sebelum operasi. Pada penelitian ini kedua antibiotik dilarutkan dalam aqua pro injeksi 5-10 mL dan diinjeksikan pada pasien dengan kecepatan < 5 menit secara IV push (IVP) dan IV piggyback (IVPB). Rute pemberian pada kedua kelompok uji disajikan pada tabel IV. Sebanyak 4 subyek $(9,8 \%)$ dari kelompok cefazolin dengan rute pemberian IVP dan 12 subyek (29,3\%) pada kelompok ceftriaxone mengalami efek samping. Total insidensi efek samping pada rute pemberian antibiotik secara IVP sebesar 16 subyek dan tidak terdapat efek samping pada rute pemberian secara IVPB. Insidensi efek samping pada kedua kelompok terapi disajikan pada tabel IV.

Manifestasi klinis insidensi efek samping pada peneltian ini sebanyak 4 subyek dari kelompok cefazolin dengan dosis 1-2 gram mengalami efek samping mual, muntah serta tidak ditemukan keluhan flebitis. Sebanyak 12 subyek pada kelompok ceftriaxone dengan dosis 1-2 gram ditemukan efek samping berupa kejadiaan mual, muntah serta keluhan flebitis. Dari 12 subyek pada kelompok ceftriaxone yang mengalami efek samping mual muntah terdapat 8 subyek $(66,67 \%)$ diantaranya mengeluhkan flebitis. Manifestasi klinik insidensi efek samping pada dua kelompok uji disajikan pada tabel V. 
Tabel IV. Insidensi Efek Samping Cefazolin Dan Ceftriaxone pada Pasien Bedah Obstetri Dan Ginekologi Periode Januari - Juni 2020 Di RSUD Dr. Dradjat Prawiranegara Serang

\begin{tabular}{|c|c|c|c|c|}
\hline \multirow{2}{*}{ Variabel } & \multicolumn{2}{|c|}{ Efek Samping } & \multirow{2}{*}{$\mathbf{P}$} & \multirow{2}{*}{$\begin{array}{c}\text { RR } \\
95 \% \mathrm{CI} \\
\end{array}$} \\
\hline & Tidak Ada & Ada & & \\
\hline \multicolumn{5}{|l|}{ Antibiotik } \\
\hline Cefazolin & 37 (90.2\%) & $4(9.8 \%)$ & 0,033 & $0,33(0,076-0,895)$ \\
\hline Ceftriaxone & $29(70.7 \%)$ & $12(29.3 \%)$ & & \\
\hline \multicolumn{5}{|l|}{ Rute Pemberian } \\
\hline i.v. Push $<5$ meit & $0(0 \%)$ & $16(100 \%)$ & 0,000 & - \\
\hline $\begin{array}{l}\text { i.v. Piggyback }>5 \text { menit } \\
\text { Dosis }\end{array}$ & $66(100 \%)$ & $0(0 \%)$ & & \\
\hline $1 \mathrm{gr}$ & $9(75 \%)$ & $3(25 \%)$ & 0,605 & $1,03(0,347-6,160)$ \\
\hline $2 \mathrm{gr}$ & $57(81,4 \%)$ & $13(18,6 \%)$ & & \\
\hline
\end{tabular}

Tabel V. Manifestasi Klinis Insidensi Efek Samping Cefazolin dan Ceftriaxone pada Pasien Bedah Obstetri dan Ginekologi Periode Januari - Juni 2020 Di RSUD dr. Dradjat Prawiranegara Serang

\begin{tabular}{lcc}
\hline \multicolumn{1}{c}{ Antibiotik } & Manifestasi Klinis & $\mathbf{n} \%$ \\
\hline & & $\mathrm{n}=4$ \\
Cefazolin 1 -2 gr & Mual muntah & $4(100 \%)$ \\
& & $\mathrm{n}=12$ \\
Ceftriaxone 1-2 gr & Mual muntah & $4(33,3 \%)$ \\
Ceftriaxone 1 -2 gr & Mual muntah dan flebitis & $8(66,67 \%)$ \\
\hline
\end{tabular}

Hasil penelitian ini menunjukkan bahwa insidensi efek samping yang terjadi pada kedua kelompok terdapat perbedaan yang bermakna $(p=0,003)$ dengan probabilitas insidensi efek samping ceftriaxone sebesar 0,33 kali dibandingkan cefazolin. Cefazolin memiliki tingkat keamanan yang lebih baik dibanding ceftriaxone dengan jumlah insidensi efek samping sebesar $9,8 \%$ vs $29,3 \%$.

Sejalan dengan penelitian ini, penelitian yang dilakukan oleh Mars $\mathrm{dkk}^{24}$ dengan tujuan membandingkan keamanan beta laktam secara IVP sebagai alternatif dikarenakan kekurangan persediaan pelarut volume kecil seperti kemasan piggyback (50-100 mL) di rumah sakit, sebanyak total 1000 pasien, $10(1 \%)$ mengalami efek samping flebitis dan eosinofilia karena pemberian ceftriaxone secara IVP dengan durasi $<5$ menit ${ }^{24}$. Sebanyak 6 pasien mengalami efek samping yang spesifik terkait pemberian ceftriaxone 2 gram secara IVP dengan kecepatan < 5 menit dikaitkan dengan palpitasi, takikardia dan flebitis grade $2^{25}$. Ceftriaxone secara IVP dengan kecepatan 2 - 4 menit juga telah dilaporkan terjadinya peningkatan pseudolitiasis bilier pada anak anak dan pembentukan endapan kalsium pada pemberian bersama dengan larutan yang mengandung kalsium menyebabkan kardiopulmoner yang mengancam jiwa ${ }^{26}$. Studi retrospektif yang menganalisis 113 kasus adverse drug reaction dengan melibatkan 17 jenis antibiotik beta laktam secara IVP diantaranya proporsi ceftriaxone 32 pasien $(28,3 \%)$ dan cefazolin 7 pasien $(6,19 \%)$. Manifestasi klinis yang dilaporkan berupa kerusakan kulit (flebitis, edema, rash dan pruritis) $62,83 \%$, aritmia $13,27 \%$ dan digestive system (nausea, vomiting, diare) 7,96\% $\%^{27}$. 
Ceftriaxone di laporkan dominan menyebabkan efek samping flebitis, kerusakan sistem saraf dan sistem gastrointestinal, namun proporsi ceftriaxone tidak disebutkan secara rinci ${ }^{27}$. Keamanan penggunaan cefazolin secara IVP dan IVPB didukung dalam studi observasional prospektif yang terdiri dari 240 subyek dewasa dengan prosedur bedah ortopedi, tidak ada perbedaan dalam tingkat flebitis pada subyek yang menerima cefazolin IVPB lebih dari 30 menit dibandingkan dengan IVP selama 3 - 5 menit $(3,4 \% \text { vs 3,3\%; } p>0,05)^{28}$. Cefazolin sebagai antibiotik profilaksis yang direkomendasikan di sebagian besar prosedur pembedahan memiliki keamanan lebih baik dengan jumlah kejadian flebitis dan adverse event lainnya lebih rendah dibandingkan cefriaxone, ceftazidim dan cefepime $(p=0,007)^{24,}$.

Pemberian antibotik golongan cephalosporin secara IV push yang disetujui food and drug administration (FDA) diantaranya adalah cefazolin, cefotaxime, cefotetan, ceftazidime dan cefuroxime. Meskipun ceftriaxone dan cefepime tidak disetujui pada rute pemberian secara IV push namun dengan rute tersebut masih dapat diberikan ${ }^{25,29}$. Untuk kebanyakan prosedur pembedahan, cefazolin adalah obat pilihan sebagai profilaksis bedah karena merupakan agen antimikroba yang paling banyak dipelajari dengan kemanjuran yang telah terbukti, keamanan yang memadai, dan biaya yang rendah ${ }^{16}$. Profil farmakokinetik cefazolin memungkinkan durasi tindakan bedah yang diinginkan dan memiliki spektrum aktivitas melawan organisme yang biasa ditemui dalam pembedahan ${ }^{16}$.

Dari banyak faktor yang menyebabkan flebitis, osmolaritas dan kecepatan rute pemberian berpengaruh terhadap adverse event. Pemberian obat dengan osmolaritas > $900 \mathrm{mOsm} / \mathrm{L}$ melalui vena perifer dianggap menempatkan pasien pada risiko lebih tinggi untuk terjadinya flebitis ${ }^{24}$, namun penelitian Gandhi dan Elshaboury ${ }^{30}$ yang melakukan pengujian osmolaritas dari berbagai beta laktam yang dilarutkan dalam $10 \mathrm{~mL}$ natrium klorida 0,9\% didapatkan konsentrasi ceftriaxone 1 gram dalam $10 \mathrm{~mL} \mathrm{NaCl} \mathrm{0,9 \%}$ adalah $658 \mathrm{mOsm} / \mathrm{L}$ dan cefepime 1 gram dalam $10 \mathrm{~mL} \mathrm{NaCl} \mathrm{0,9 \%} \mathrm{adalah} 1.040 \mathrm{mOsm} / \mathrm{L}$, meskipun cefepime memiliki osmloaritas yang tinggi namun pada konsentrasi ini flebitis tidak terjadi dan menyimpulkan bahwasanya durasi $<5$ menit yang menyebabkan terjadinya efek samping ${ }^{30}$. Penggunaan ceftriaxone yang luas secara klinis, efek samping yang terjadi juga secara bertahap meningkat ${ }^{27}$. Ceftriaxone adalah golongan sefalosporin yang tidak memiliki imunogenitas dan tidak menyebabkan alergi, tetapi pengotor polimernya yang tinggi merupakan alergen utama $^{27}$. Polimer yang tinggi terdegradasi didalam tubuh dan bereaksi secara permanen dengan protein, peptida dan pembawa makromolekul lainnya di dalam tubuh sehingga terjadi reaksi antigen-antibodi yang menyebabkan flebitis dibandingkan sefalosporin lainnya ${ }^{27}$.

Data mengenai efektivitas dan keamanan ceftriaxone dibandingkan cefazolin dalam penelitian ini dapat membantu klinisi dalam memilih antibiotik profilaksis sesuai panduan. Data tersebut sangat diperlukan untuk meningkatkan kualitas dari suatu prosedur pembedahan, mencegah ILO dan mencegah resistensi antibiotik. Data ini juga membantu Apoteker dalam melakukan evaluasi penggunaan obat sesuai dengan Standar Pelayanan Kefarmasian di Rumah Sakit yang telah diatur dalam Permenkes RI Nomor 72 Tahun 2016 31 . Namun demikian penelitian ini memiliki kelemahan yaitu monitoring efek samping obat pada kedua kelompok antibiotik tidak menggunakan algoritma naranjo sehingga menimbulkan intepretasi yang berbeda antara apoteker klinis dan perawat bangsal bedah dalam penilaian kondisi klinis serta keluhan pasien terkait efek samping obat.

\section{KESIMPULAN}

Cefazolin memiliki efektivitas yang sama dengan ceftriaxone sebagai antibiotik profilaksis dalam mencegah kejadian ILO. Cefazolin juga memiliki keamanan yang lebih 
baik dibandingkan ceftriaxone. Hasil penelitian ini dapat menjadi bahan pertimbangan bagi klinisi bedah obsgin dalam menggunakan antibiotik profilaksis secara rasional untuk mencegah timbulnya resistensi dalam praktik rutin di rumah sakit.

\section{DAFTAR PUSTAKA}

1. Torres B, I S, Umscheid craig. A. Centers for Disease Control and Prevention Guideline for the Prevention of Surgical Site Infection, 2017. JAMA Surg. 2017;152(8):784-791.

2. Chairani F, Puspitasari I, Asdie RH. Insidensi dan Faktor Risiko Infeksi Luka Operasi pada Bedah Obstetri dan Ginekologi di Rumah Sakit. J Manaj dan Pelayanan Farm Univ Gajah Mada. 2019;9(4):274-283

https://jurnal.ugm.ac.id/jmpf/article/vie $\mathrm{w} / 48024$.

3. Sumarningsih P, Yasin MN, Asdie HR. Effect of Risk Factors on the Occurrence of SSI in Patients with Obstetrics and Gynecology Surgery at Dr. RSUP Sardjito Yogyakarta. Maj farmasetik. 2020;16(1):43-49.

4. Pathak A, Mahadik K, Swami MB, et al. Incidence And Risk Factors For Surgical Site Infections In Obstetric And Gynecological Surgeries From A Teaching Hospital In Rural India. Antimicrob Resist Infect Control. 2017;6:18.

5. Oh AL, Goh LM, Abdullah N, et al. Original Article Antibiotic usage in surgical prophylaxis: a prospective surveillance of surgical wards at a tertiary hospital in Malaysia. J infect Ctries. 2014;8.

6. Alfouzan W, Fadhli M, Abdo N, Alali W, Dhar R. Surgical site infection following cesarean section in a general hospital in Kuwait: trends and risk factors. Epidemiol Infect. 2019. https://pubmed.ncbi.nlm.nih.gov/31597 $580 /$
7. Baron S, Jouy E, Larvor E, Eono F, Bougeard S. Impact of ThirdGeneration-Cephalosporin

Administration in Hatcheries on Fecal Escherichia coli Antimicrobial Resistance in. 2014;58(9):5428-5434. https://aac.asm.org/content/58/9/5428

8. PPRA. Pedoman Penggunaan Antimikroba Profilaksis dan Terapi. In: RSUD Dr. Dradjat Prawiranegara Serang. ;2018.

9. Hussain Z, Curtain C, Mirkazemi C, Gadd K, Peterson GM, Zaidi STR. Prophylactic Cefazolin Dosing and Surgical Site Infections: Does the Dose Matter in Obese Patients? Obes Surg. 2019;29

(1):159-165. https://pubmed.ncbi.nlm.nih.gov/30267 229/

10. Pop-vicas A, Mls SJ, Safdar N. Cefazolin as surgical antimicrobial prophylaxis in hysterectomy: A systematic review and meta-analysis of randomized controlled trials. Infect Control Hosp Epidemiol. 2018:1-8.

11. Phoolcharoen N, Nilgate S, Rattanapuntamanee O. A randomized controlled trial comparing ceftriaxone with cefazolin for antibiotic prophylaxis in abdominal hysterectomy. Int $J$ Gynecol Obstet. 2012;119(1):11-13.

12. Jyothi S, M VN, Pratap K, Asha K. Antibiotic prophylaxis for hysterectomy and cesarean section: Amoxicillinclavulanic acid versus cefazolin. $J$ Obs Gynecol India. 2010;60(5):419-423. https://www.ncbi.nlm.nih.gov/pmc/arti cles/PMC3394618/

13. James D, Steer P, Weiner C, Crowther C. Studies: A Reference Table for Clinicians To the Editor: In Reply: ACOG Pract Bull Clin Manag Guidel Obstet. 2010:868. https://journals.lww.com/greenjournal/ Citation/2010/04000/Pregnancy_and_La boratory_Studies_A_Reference.35.asp $\mathrm{x}$ 
14. Sastroasmoro Sudigdo, Ismael Sofyan. Dalam: Sastroasmoro, Sudigdo dan. In: Dasar-Dasar Metodologi Penelitian Klinis.; 2011:384-385. https://opac.perpusnas.go.id/DetailOpa c.aspx?id=1111569

15. Dahlan S. . Besar Sampel dan Cara Pengambilan sampel dalam Penelitian Kedokteran dan Kesehatan seri 2 edisi 4. In: Besar Sampel Dan Cara Pengambilan Sampel Dalam Penelitian Kedokteran Dan Kesehatan.; 2016:105. https://opac.perpusnas.go.id/DetailOpa c.aspx?id=699349

16. Bratzler DW, Delinger P., Olsen KM, Peri TM. Clinical practice guidelines for antimicrobial prophylaxis in surgery. ASHP Rep. 2013;70:195-283.

17. Shenoy D, Nalluri K, Manasa C, Reddy P, Srinivasan R. Journal of Drug Delivery and Therapeutics A study on evaluation of risk factors and antimicrobial prophylaxis in the prevention of surgical site infection. J Drug Deliv Ther. 2019;9:159-166. http://jddtonline.info/index.php/jddt/ar ticle/view/2477

18. Anderson JD, Sexton JD. Antimicrobial prophylaxis for prevention of surgical site infection in adults. Up to Date. 2018;1-35:90.

https://www.uptodate.com/contents/an timicrobial-prophylaxis-for-preventionof-surgical-site-infection-in-adults

19. Mamo T, Abebe TW, Chichiabellu TY, Anjulo AA. Risk factors for surgical site infections in obstetrics: a retrospective study in an Ethiopian referral hospital. Patient Saf Surg. 2017;11:24:1-9.

20. Kemenkes RI. Pedoman Umum Penggunaan Antibiotik. Peraturan Menteri Kesehatan RI Nomor 2406/Menkes/Per/XII/2011.

http://iai.id/library/pelayanan/permenk es-no-2406-thn-2016-ttg-pedomanumum-penggunaan-antibiotik

21. AL Jama EF. Risk factors for wound infection after lower segment cesarean section. Qatar Med J. 2012;2012(2). https://pubmed.ncbi.nlm.nih.gov/25003 037/

22. Allen J, David M, Veerman JL. Systematic review of the costeffectiveness of preoperative antibiotic prophylaxis in reducing surgical-site infection. BJS Open. 2018;(Cdc).

23. POGI. Perkumpulan Obstetri Dan Ginekologi Indonesia Indonesian Society Of Obstetrics And Gynecology. Perkumpulan Obstet Ginekol Indones. 2013. https://pogi.or.id/publish/

24. Marsh K, Ahmed N, Decano A, Pung S, Jie X. Safety of intravenous push administration of beta-lactams within a healthcare system. Am J Heal Pharm. 2020;77(9):8-11.

25. Spencer $\mathrm{S}$, Ipema $\mathrm{H}$, Hartke $\mathrm{P}$, et al. Intravenous Push Administration of Antibiotics: Literature and Considerations. SAGE. 2018;53 (3)(Mc 886).

26. Bradley JS, Wassel RT, Lee L, Nambiar S. Intravenous Ceftriaxone and Calcium in the Neonate: Assessing the Risk for Cardiopulmonary. J Pediatr. 2020;123(4).

27. Lu J, Cai C, GU Y, Tang Y. Analysis On 113 Cases Of Adverse Reactions Caused By B-Lactam Antibiotics. Tradit Complement Altern Med. 2013;10:83-87. https://www.ncbi.nlm.nih.gov/pmc/arti cles/PMC3794396/

28. Biggar C, Nichols C. Comparison of Postinfusion Phlebitis in Intravenous Push Versus Intravenous Piggyback Cefazolin. Art Sci Infus Nurs Art Sci Infus Nurs. 2012:384-388.

29. Mclaughlin JM, Scott RA, Koenig SL, Mueller SW. Intravenous Push Cephalosporin Antibiotics in the Emergency Department. Adv J. 2017;39(4):295-299.

30. Gandhi R., Elshaboury SN. I.V. push administration of medications reconstituted with $0.9 \%$ sodium chloride injection. Am J Heal Pharm. 2018;75(12):851-852. 
Uji Perbandingan Antibiotik Profilaksis Ceftriaxone versus Cefazolin

31. Kemenkes RI. Standar pelayanan kefarmasian di Rumah sakit Peraturan menteri kesehatan RI no 72 tahun 2016. Standar pelayanan kefarmasian di Rumah sakit. 2016; (72): 2016.

https://peraturan.bpk.go.id/Home/Deta ils/114491/permenkes-no-72-tahun2016 